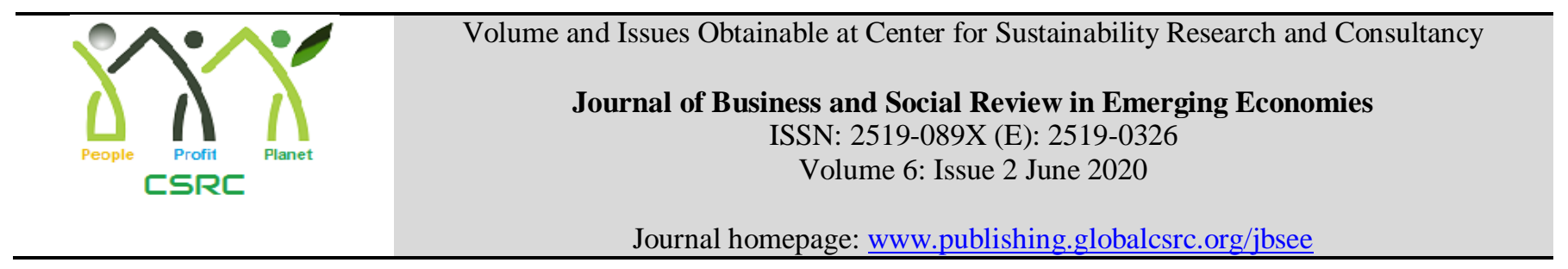

\title{
Dependence of Editorial Independence, Influence of Economic Factors on News Channels in Pakistan
}

\section{${ }^{1}$ Ghulam Shabir, ${ }^{2}$ Atif Ashraf, ${ }^{3}$ Farasat Rasool, ${ }^{4}$ Qamar-uddin-Zia Ghaznavi}

${ }^{1}$ Professor, faculty of Media and Communication Studies, University of Central Punjab, Lahore Pakistan, drshabair@yahoo.com.pk

${ }^{2}$ Assistant Professor, Faculty of Media and Communication Studies, University of Central Punjab, Lahore Pakistan

${ }^{3 \& 4}$ Assistant Professor, School of Media and Communication, Beacon House National University, Lahore Pakistan

\begin{tabular}{l}
\hline ARTICLE DETAILS \\
\hline History \\
Revised format: May 2020 \\
Available Online: June 2020 \\
\\
\hline Keywords \\
Editorial autonomy, economy, \\
PEMRA, news channels, \\
broadcast journalists, invisible \\
pressures, media \\
responsibility, democracy, \\
newsroom, Political
\end{tabular}

ABSTRACT
Private news channel in Pakistan get sponsorships and commercials from state
as well as from private companies to run their businesses. Selling ads may lead
to sell content shaped in favor of the sponsor. This study has analyzed the
influence of commercialization on editorial autonomy of broadcast journalists
of Pakistan. A survey of senior journalists from top ten news channels was
conducted to analyse perception of the professionals about the influence of
commercialization on the content of news and current affairs. It is found that
economic pressures restrain newsroom staff to make editorial decisions
independently.

\section{JEL Classification}

$M 1, M 11$

OPEN ACCESS

(C) 2020 The authors, under a Creative Commons Attribution-

NonCommercial 4.0

Corresponding author's email address: drshabair@yahoo.com.pk

Recommended citation: Shabir, G., Ashraf, A., Rasool, F. and Ghaznavi, Q. Z. (2020). Dependence of Editorial Independence, Influence of Economic Factors on News Channels in Pakistan. Journal of Business and Social Review in Emerging Economies, 6(2), 883-892

\section{Introduction}

Mass Media, especially News Channels in Pakistan contributes to shape public opinion regarding news and current affairs. But there are journalists who shape media contents and the content is shaped by the journalists routine practice as per the official policy. Journalists have to follow possible pressures that limit their editorial autonomy during practice. Freedom of media may be restricted by the advertisers, the official policy, organizational economic interests and sponsorship. In this scenario the level of editorial independence of the professionals needs to be calculated by analyzing perception of the working journalists about the economic factors that shape media content, that may be controlled by the advertisers. 
Keeping in view the scope of the study, the researcher has narrowed down the Pakistani media industry to private news channels only. According to Media Logic, the only TV Audience measurement [TAM] data providing Company in Pakistan, the leading ten news channels of Pakistan based on three monthly reports of ratings are, Express News, Samma, Geo News, ARY News, Dunya News, AAB TAK, AAJ News, Dawn News, News One and Ninety-Two News (Media Logic, 2015).

The perception of professionals about how they are free from any influence of economic interest while creating content has been analysed by focusing TV newsroom only. Because a newsroom is the central place where editorial staff including editors and producers work to gather, edit and filter news to broadcast. In this study, professionals have been limited to the editorial staff of the news room of private TV channels. These newsroom media professionals have to bear economic pressures in practicing journalism freely. Perception of these professionals, can best tell about the current state of editorial autonomy of broadcast journalists in the country.

The newsroom journalists work in head offices of the leading news channels where news agenda is set. The newsroom gets raw information from reporters, monitoring and other newsfeed, and then process the information under supervision of a director news who is answerable to the owner. In the newsroom environment a newsroom journalist knows best about the economic factors affecting the autonomy during practice. What content should go on air and what should be restricted, years of experience has developed the journalists' perception. This study will assess limits of media freedom into minds of journalists.

\subsection{Statement of the Problem}

Freedom of expression is basic right of citizens as per constitution of the country but the Pakistan ranks 159th position in the world press freedom index. (World Pres freedom Index 2015, 2015). This index puts Pakistan on "not free" status as far as media freedom is concerned. The regimes in Pakistan have been claiming that after the emergence of private TV channels, Pakistani Media are free but the situation seems other way round.

Previous researchers have adopted different areas to study media freedom in Pakistan. Researchers measured media freedom from journalists' perception to journalists-government relations, government influence on media content to public survey and analyzing contents based on previous findings at international and national level. But this study focuses journalists' perception about "how much their pen is free from economic restraints to practice journalism freely". This study assessed the editorial autonomy of newsroom editorial staff that may lead to open ways to make a mechanism to restrain the economic factors especially influence of advertisers on the journalists' editorial autonomy. Because it the journalist independence that lead to media independence and to present neutral content for the audience so that they could make decisions based on reality.

\subsection{Rationale}

As there are different filters and gatekeepers in TV industry where content is modified or rejected on the basis of merit, policy or any other pressure. The study will practically test media freedom and editorial independence in Pakistan because content generators. i.e. the journalists can paint the picture of press freedom with brush of their perception. Journalists are part of media who generate contents after a numbers of filters. Evolution the quality of freedom of media may lead evaluation in democracy. As Joseph M K also said that media are as much as protector of national freedom, sovereignty and the qualities of civilizations as legislature or the judiciary (Joseph, 1997).

Keeping in view Joseph's approach, in a country like Pakistan where democracy and dictatorship have been overlapping each other, as martial law has been imposed four times since independency of the country in 1947, it is very important to explore level of press freedom to determine state of democracy, sovereignty and national freedom in Pakistan. Another important reason to conduct this study is that audience can easily see the transmitted news agenda on TV screen but could not see the agenda being hidden from them by the news room.

\subsection{Objective of the Study}

To measure current state of editorial independence of journalists in Pakistan at economic level

To find out possible economic factors that restrict freedom of expression by the journalists. 


\subsection{Research Question}

Q.1. Do the professionals think economic factors controls practice of editorial independence?

Q.2. What is role of TV commercials in shaping news and current affairs contents of News Channels?

\subsection{Hypothesis}

H.1. The more clients will give ads to media, the more they will have influence on its contents

H.2. Media owner's interference restricts journalists to practice freedom

H. 3. The more a source will be influential, the more journalists will surrender editorial freedom.

\section{Literature Review}

Free Media and an open society go hand in hand, but if mass media is monopolized, it can be turned into a weapon of 'mass deception'. In case of Pakistan, it seems mass media have achieved a certain level of autonomy. Since the birth of private TV channels in Pakistan, control of state owned TV channel, Pakistan Television (PTV) on content broadcasting has come to an end. As Waseem (2006) also argues that the growth of private TV channels has ended domination of the state owned broadcast. Many Pakistani viewers now watch international broadcast through cable. This trend has given more control to the audience over the communication process. Today there is an open competition broadcast system, that enables the active-audience enjoy more power of selective exposure.

According to Media Logic, "the most watched cable news channel in Pakistan is the commercial Geo News, while Express News, Samaa TV, Dunya TV, Aaj TV, and Dawn News all rank high in terms of ratings and reach." (Media Logic 2015). But after the launch of privately owned news channels, media market has been diversified.

The rapid emergence of privately owned news channels on cable, has also changed the pace of the newsroom working. The professionals now always work under-pressure to produce content in the competitive market round the clock. As Mr Hameed says, "If we lack in content, we have to arrange and create some. We have to make light content into hard one." (Hameed, 2016)

TV journalists complain that they are forced to deliver content that boost ratings and so journalistic value is compromised. Practice of re-broadcasting news after first aired by a rival channel without verifying the information is a journalistic routine to keep ratings high. (Hameed 2016). So editorial staff in newsroom is always in a practice of taking directions from top management for content, filtration, management and transmission compromising their editorial independence for a free content transmission and fulfilling agendas of pay masters.

Open society report on Pakistani media says that liberalization of the electronic media went to greater media independence between 2002 and 2007. In his study, Yousuf (2013) claimed that "increased competition and widespread cross-media ownership since 2007 have undermined gains in media freedom and diversity." (Yousuf, H, 2013).

According to Siraj (2008) the government dominates the press autonomy by using advertisement as its tool and 33\% share of advertisements is used as leverage to control media. Therefore, he says, the state run broadcast TV channels act as a propaganda tool of the government. (Siraj, 2008)

Previous literature also suggests that Freedom of media is affected by advertisements; it is a common practice of governments to use advertisements as a tool to control media content. Commercial interests also restrict media freedom and democracy as Andrew Sullivan of Daily Dish said to BuzzFeed's Ben Smith: "If journalism is not understood to be separate from advertising, then it has lost something incredibly important in a democratic society" (Rowan, 2015).

Clement Asante (1997) does not sees a complete freedom for the press. He says, "there are levels or degrees of the freedom. No country in the world has an absolute freedom of the press but different degrees of the freedom" (Clement, 1997). And scholars say due to this simple fact it is difficult to define freedom of the press in universal terms.

George Githii (1971; cited in Asante, 1997) suggests that any serious discussion concerning the definition of press freedom essentially include economic, social, cultural and political factors. Hallin and Mancini (2004: 3) see media function under different political, cultural, economic and societal systems that influence to adapt and apply theories on 
press-government relationship.

Extant literature says the entire process of media content dissemination to the general public includes variety of interests. These interests are personal interests, source interest, and ownership interests. The key interests also include status of politicians, agenda of any interest groups, policy inferences for governments, size of the target market, preferences of the audience and reputation of advertisers' products (McManus 1994; Schudson 2003; Strömbäck \& Karlsson 2011).

Scholars believe that all these interests combine together damage the competence of journalists to distribute the news content in time with objectivity to the audience.

In the study "The Impact of Censorship on the Development of the Private Press Industry in Myanmar", Kyaw Thu after conduction survey of working journalists regarding state sponsorship, concluded that censorship has had a huge impact in private press of Myanmar as it is controlled by the state with almost no room for watch-dog role. Censorship has destroyed impartiality of news and had weakened the role of media in democratization of society. (Thu, 2012)

Other studies with journalists in developing countries have recognized many similarities in identifying some forces that shape media content (David Weaver, 2000, 2002). In their study "Modeling Perceived Influences on Journalism: Evidence from a Cross-National Survey of Journalists”, Thomas Hanitzsch et all, conducted survey of 1,700 journalists from seventeen countries. They concluded that "perceived influences on news work disclose structure of six distinct domains_-political, economic, organizational, professional, and procedural influences, as well as reference groups".

According to Leeson and Coyne, governments may pursue to regulate flow of information with monopolizing media ownership or exerting economic pressure on private mass media to give content coverage in in a positive way (Leeson and Coyne, 2005). Flegel and Chaffee (1971) were among the first who empirically explored the journalists' perceptions of influences. In their study, based on perception of 17 reporters in Wisconsin, they found the readers' interests as a big influence on editorial content and advertisers influence came with minimum effect. (Flegel \& Chaffee, 1971). Weischenberg, Löffelholz and Scholl (1993) applied the same research approach in a survey of German journalists finding that "the journalists basically rely on their colleagues and peers' professional views. The interviewed journalists evidently perceived the newsroom working environment has influence than external factors" (Weischenberg, 1993).

Bashir Memon (2014) analysed perception if Sind journalist about media freedom concluding that media objectivity is not being followed freely owing to media organization owners, governments, politicians, various interest groups, advertisers and audiences. (Memon 2014).

Research literature also indicates that journalistic autonomy is based on the liberty to speak and publish, and freedom from interference in that activity as well (C.F. Carpentier 2005). Autonomy also refers to the freedom that a professional has in performing duties at the level of journalistic practice (Reich \& Hanitzsch 2013: 135).

For Altschull, government regulations and licenses; the interests of publishers, and advertisers; political parties, religious groups shape content at the cost of journalistic autonomy. Altschull (1997: 260) argues that, "the content of the press is directly correlated with the interest of those who finance the press".

For LaMay, "Commercialism in media is also one of limiting factors for press freedom as powerful groups may abuse libel and complaints proceedings to silence critical media and in fear of these proceedings, journalists apply selfcensorship, which in turn also limits press freedom" (LaMay 2007).

How much advertisers snub media freedom? scholars have similar findings. Baker (2002), sees advertisers' influence as corrupting, Whereas Fiss (1986) points figure at capitalism who always win against media freedom. Curran (2002) also argues, Media outlets have become more profit oriented. Kim (2002) focuses mainly of ownership area, and sees owners control on editorial content as restrictions to media freedom. In his view, "journalists are forced to follow their company's policy as employees. As a result, they serve for the profit rather than for the public service role" (Kim 2002). 


\section{Theoretical Framework}

This study employs a theoretical framework of political economy of mass media and theories of news production (media sociology) to unearth the economic forces influencing media freedom in Pakistan. As per the existence literature, editorial autonomy is assessed in terms of social relations having cultural, economic and political dimensions. Shoemaker (Shoemaker 1991) also relates to Herman and Chomsky findings that see journalists as gatekeepers who tend to manufacture consent for leading interest groups because journalists trust on information given by them (Herman \& Chomsky 1988: 298).

Mosco (1996) says political economy of the media focusses on the set of social relations organized around power to control the production, distribution and consumption of news content. This coincides with the viewpoint of Herman and Chomsky (1988) who, too, acknowledge the relationship between political power and news production. This helps them control and manipulate public opinion by exploiting media for personal gains. It is in the interest of media owners and controllers to pay a mere lip service to liberal-pluralistic ideals.

The Political Economy is a focal point in the research. The viewpoint says those who own and control the media have an upper hand as their interests are protected. Therefore, role of owners has become most important in a media organisation. The ruling class exerts control over media institutions and ownership is thought to be the primary way the ruling class choses to drive towards its goals. Eventually it is the political economy view that gives room to expect that if media is owned by capitalist, editorial decisions and media content will definitely tend to favor the people with economic power. The viewpoint also argues that if media ownership is change, it does not necessarily affect power relations because each owner's way connects to the same road and that road is "interests of capital".

Scholars have discussed different variations in owners control. Altschull (1984) also suggested a framework to study these variations saying media reflect the ideology of those who finance them He gives four bases of media support that bases are official, commercial interest and informal patterns of mass media. Elaboration the four sources, he says media are controlled by the state as official pattern, imitate the advertisers' ideology as the commercial arrangement and finally media content echoes the ideology of that group which finances it as per the interest patterns. He also elaborates that media content also reflects the objectives of individual contributors who use it for promotion of their views as informal pattern. The patterns under discussion, he argues, vary from country to country within nations with the passage of time. Ultimately, the patterns define the media freedom as if it is free, state-controlled, or in control of the paymaster.

Whether mass media is a mission or a business? The answer has been best described in political economy of mass media. Edward Herman and Noam Chomsky introduced propaganda model of media in their "Manufacturing Consent - The Political Economy of the Mass Media" published in 1988. The Propaganda Model of media operations tells about how communicative ideological power link with political, economic and social power. This model also examines the resulting effects on content transmission of media. Herman and Chomsky see most of the mass media outlets as large corporations and wealthy people control them. They also argue that media managers who control the content are directly controlled by owners and other market-profit-oriented forces with sharp constraints. This model points to the "five filters" in society that govern treatment of news by the media outlets. News items are either influenced by commercial interests or influential restrictions; hence press freedom is limited by the concept of free market ideology because owners of the media corporations are here to make business. The theory suggests five filters that decide "merit" of a news item to be presented in mass media. These classes are, Ownership, size and profit of the medium, Funding sources of the medium (Advertisers), Sourcing Flak and fear ideology.

As advertising is the main source of revenue for commercial media, therefore interests of the Advertisers and the market are carefully taken care of. Summing up the model, first two filters suggest, i,e. ownership and advertisers of the political-economic dimensions exert heavy influence on news production and execution to shape news content. The third filter i.e. the "sources" explores the ways in which news are socially constructed- (Herman and Chomsky, 1988, 19-23; Klaehn, 2005a, 4-7). The sources that are affiliated with the institutions also dominate news discourses. Therefore, at the end, news also reflects interests of the institutions at macro level too. 
The forth filter of the model stresses role power into play. It says that actors in leading institutional have control of social-political power and using that control they also control over media performance (Herman and Chomsky, 1988, 26; Klaehn, 2005a).

For the authors, theses four filters play a key role in the process of news production. But as the fifth filter was originally 'anti-communism' but after the fall of communism, mainly in post USSR, this filter has been changed and referred refer to "dominant ideological elements". In addition to state laws, media freedom is also curtailed by these five filters. As advertisement is the sole income of the media in Pakistan, owners of media outlets carefully impose and filter news agenda to grow business. Big organizations have substantial over control media content. Public messages can also be suppressed if they clash with their interests.

\subsection{Research Design}

The study is quantitative in nature; research design is based on survey. To get perception of media professionals survey method have been designed. Close ended questionnaire was distributed to the newsroom staff of top ten news channels of Pakistan. The targeted channels were Express News, Samma, Geo News, ARY News, Dunya News, AAB TAK, AAJ News, Dawn News, News One and Ninety-Two News based in Lahore and Karachi. In this study, economic factors affecting news contents are considered as independent variables and journalists' practice, after exposing to these factors, is reflected as the dependent variable. Population of the study is editorial staff of all private news channels of Pakistan and a purposive sample has been chosen from head offices of the news channels based in Karachi and Lahore. The questionnaire has been made in Likert scale following the steps of survey method of Reporters Without Borders. Sampling size was 200 journalists from ten channels with frequency of 20 journalists from each channels. Only those news room editorial staff was approached who had minimum five years of broadcast experience. Because journalist bodies in Pakistan like Lahore Press Club and Karachi Press Club give memberships top only those journalists who have minimum experience of five years. Furthermore "editorial staff' included those broadcast journalists who process content as Assignment Editors, Rundown Producers, Copy Editors and Production staff.

\section{Data Analysis}

Data collected from 200 broadcast journalists working in top ten news channels of Pakistan with minimum five years of experience shows that in perception of journalists, they are not free to practice journalism because of various economic factors. Ordinal scale on Media freedom or editorial independence implies measurement of media freedom in perception of professionals. If economic pressures curtail media freedom? The scale is as follows, $1=$ Strongly Disagree, 2= Disagree, 3= Neutral, 4= Agree and 5= Strongly Agree. The data analysis indicates that economic pressures are found to be important influencing factor that restricts media freedom in Pakistan. As the table indicates that mean value of 3.9 points to the picture of economic environment in Pakistan. Most of the respondents agree that economic factors confine media practice and editorial autonomy.

\section{Economic Environment on Media Freedom}

\begin{tabular}{ll}
$\mathrm{N} \quad$ Valid & \multicolumn{2}{c}{200} \\
\hline \multicolumn{1}{c}{ Missing } & 0 \\
Mean & 3.9023 \\
Median & 3.9364 \\
Std. & \\
Deviation & .74924 \\
\hline
\end{tabular}

\subsection{Demographics}

In this study, demographics characteristics have not been evaluated as independent variables. All the respondents were treated as newsroom journalists regardless of their demographics. There were 166 males and 31 female participants with minimum age of 25 and with minimum five-year experience. Journalists position in newsrooms of the top ten channels of Pakistan has also been described with Assignment, content, Production and Rundown. All the four 
newsroom positions directly expose to the news content that is manufactured and transmitted from newsroom.

Data shows that Government ads are a big toll to affect media freedom. As $70 \%$ of the respondents feel that news channels are economically dependent on direct or indirect government ads or subsidies. This practice of the government provide news channels a room to give favourable opinion to the government by filtering anti-government content in exchange of government advertisement revenue.

As the findings indicate that Private news channels are profit-making companies. Advertisement revenue is engine to run the functions of the company. Therefore, as literature also reveals that economy drives news channels. Herman and Chomsky in their book, Manufacturing consent, Political economy of mass media, also described political economic aspects. The five filters in their propaganda model also filter freedom in media practice in Pakistan. Findings also supports to theory. Even information is distorted to support commercial interests. $62 \%$ of the media practitioners agree to the notion that Information is distorted and facts are suppressed for commercial interests. Institutional interests may be economic political or social. But they are a big hurdle on the wake of media freedom in Pakistan. $60 \%$ of the respondents reveal that media practice in Pakistan is being influenced highly by the institutional interests.

Information is distorted means objectivity is compromised and so is editorial independence and media freedom. Besides institutional (company) interests there are many special interests that hit harder on practice of media freedom. These special interests may include marketing news of sister organization of the news channel or coverage of sponsored activities by the news channels for vested interest or any other interests. Keeping in view the special interests, $57 \%$ of the professionals agree that these interests exert pressures on practice of media freedom.

TV channels are hungry for TVCs [Television Commercials]. There is a separate marketing department that searches clients for advertisement revenue. On business point of view, client relations are so strong that sometimes news objectivity is compromised. $62 \%$ of the respondents are also of the opinion revealing that if a news comes against any of the advertisers, it does not go on air owing to the same economic interests.

Owners interference is followed widely. It is a fact that owner is a paymaster and journalists are payees. Therefore, owners' instructions are assumed above from any editorial judgments. 58\% of the respondents also put their weight in it. Professionals believe that if a news is on merit but owner of the channels has different opinion, then decision will not be taken editorially.

Same is the case with must run news. If it is assumed that sometimes owner of the news channel becomes agenda setter, it will not be wrong. As owner sees its commercial interest first, therefore marketing is labeled as "MUST" to "KILL" merit, editorial judgment or objectivity.

Source is also a powerful filter that filters editorial independence as described in the propaganda model of Herman and Chomsky. This filter is filtering same situation as described in the model. In Pakistan, reporters also give preference to their sources. So revealing negative news of the source is compromised. As $48 \%$ of the respondents also nod in favor of this trend, $25 \%$ gave no opinion and $27 \%$ were found disagree on this.

More government revenues mean less criticism and on the other hand less government ads also mean less criticism. As data in the following table also shows that $58 \%$ of the respondents think that if a news channel does not get government ads, its contents is also changes in favorable to the government to get the state commercials. This passive practice of news channels actively compromises practice of media freedom by the professionals.

The researcher gets the dominate opinion that private news channels are just profit making companies. After analyzing perception of the professionals, $71 \%$ of the broadcast journalists point fingers to the channels profit making role. There is a big difference between editorial censorship and selective censorship. Censorship is not only applied on sensitive or anti-social content; it is also applied to news items regarding product or services of advertisement clients. As data in the following talk shows that $66 \%$ of the professionals also think that revelations against product or services of advertisement clients is deliberately censored. 


\section{Discussion and Conclusion}

Keeping in view the overall impressions, findings of this study conforms to the theory of political economy of mass media as described by Edward Herman and Noam Chomsky as propaganda model in their 'Manufacturing Consent The Political Economy of the Mass Media' published in 1988. As this model argues that there are five filters in society that determine treatment of news by mass media. News are influenced by commercial interests or influential restrictions and hence press freedom is limited by the concept of free market ideology because owners of the media corporations are here to make business. Findings shows that all these five filters, i.e. Ownership, funding sources, sourcing, flak and fear ideology are also major factors in Pakistan that curtail media freedom at political. Social and economic level.

Findings of the study also conforms to the theories of influences on mass media content as critically examined by Pamela J. Shoemaker and Stephen D. Reese in their book Mediating the Message, Theories of influences on mass media content, in 1994. Both major external and internal influencings are restricting media freedom as perceived by the media professionals. In this study, media professional also feel that external influences on media contents i.e. government control, advertisers and journalist source relationship and internal influences i.e. organizational ownership and policies of primacy of economic goals have a deep impact on practicing freedom in Pakistan.

Results show that economic environment has a significance influence that curtail media freedom of broadcast journalists in Pakistan. Journalists see the TV commercials the main engine that run news channels. As TV commercials are distributed to the news channel based on viewership rating technically known as Targeted Rating Points [TRP], therefore the professionals strive to get maximum viewership by twisting and selecting the content they assume will be liked by the audience. Matter of the fact is, private news channels are profit-making companies which depend on advertisements for survival and finally advertisements drive media and media content. Advertisement revenue is engine to run the functions of the company as literature also reveals that economy drives news channels. Herman and Chomsky in their book, Manufacturing consent, Political economy of mass media, also described political economic aspects. The five filters in their propaganda model also filter freedom in media practice in Pakistan. Findings also supports to theory. Majority of Professionals feel that even information is distorted to support commercial interests.

As TV channels are hungry for TVCs [Television Commercials], therefore there is a separate marketing department that searches clients for advertisement revenue. On business point of view, client relations are so strong that sometimes news objectivity is compromised. Findings of this study show that most of professionals think that news against any of the advertisers or client is deliberately filtered.

Similarly, media owners' role is very significant in exercising media freedom. Institutional interests are directly involved with the owners. Sometimes owner agenda is accomplished after compromising news worthy issues. These institutional interests and mainly economic political and social that create a big hurdle on the wake of media freedom. Findings of this study also show that media practice in Pakistan is being influenced highly by these institutional interests.

As Information is distorted while securing institutional interests and institutional interests means objectivity is compromised and so is media freedom. But besides institutional (company) interests there are many special interests that hit harder on practice of media freedom. Majority of the respondents think that these special interests are marketing news of sister organization of the news channel or coverage of sponsored activities by the news channels for vested interest or any other interests and this practice restricts media freedom.

Owners interference is followed widely. Knowing the fact that owner is a paymaster and journalists are payees, therefore professionals think owners' instructions are assumed above from any editorial judgments believing that if news is on merit but owner of the channels interference is accepted without any resistance.

Same is the case with "must run" news. Results show majority of the Journalists think sometimes owner of the news channel becomes agenda setter and instructs to run marketing news by labeling it as "must run", bypassing editorial judgment in the newsroom.

After Ownership and advertisers, Sourcing is another powerful filter that filters editorial independence as described in 
the propaganda model of Herman and Chomsky. Same findings surfaced in this study. Majority of the respondents think that reporters give preference to their sources and avoid revealing negative news of the source. This situation is seen in TV newsroom when competitive news channels run a news against the source of a reporter but the channel of the reporter is deprived of the news because the reporter doesn't confirm or own the news in a fear of not losing the source or benefits associated with it.

Most of the professionals think news channels also give favorable coverage the ruling party in a bid to get more government advertisements. Respondents think that if a news channel does not get government ads, its contents also change in favorable to the government to get business share of government ads. Hence this passive practice of news channels actively compromises practice of media freedom by the professionals.

Results also surface a dominate opinion of professionals that private news channels are just profit making companies as $71 \%$ of the broadcast journalists agree that journalism is a business just like a profit making company.

On Censorship, professionals think, it is not only applied on sensitive or anti-social content, it is also applied to news items regarding product or services of advertisement clients giving a perceived reality that there is a big difference between editorial censorship and selective censorship because that revelations against product or services of advertisement clients is deliberately censored.

Results also show that in economic interests, journalists avoid any issue that may be a trouble maker for them. Same is the case with sensitive religious news as a religion belongs to different sects and coverage of different sects is also carefully balanced.

In nutshell the findings discussed above assert that advertisers, owner and sources exert pressures on editorial judgments and broadcast journalists are forced to surrender their editorial freedom during practice. In context of the economic environment of Pakistan, results are also in line with the formulated hypothesis. Therefore, in light of the findings of the study, H.3, H.3.1 and H.3.2 are supported.

H.3. The more clients will give ads to media, the more they will have influence on its contents [SUPPORTED] H.3.1. Media owner's interference restricts journalists to practice freedom [SUPPORTED]

H. 3.2. The more a source will be influential, the more journalists will surrender editorial freedom [SUPPORTED]

\section{References}

Altschull, J. Agents of Power. (1984). NY: Longman. http://www.fair.org/ media-woes/ official-agenda.html

Carpentier, N. (2005) 'Identity, Contingency and Rigidity: The (Counter-) Hegemonic Constructions of the Identity of the Media Professional', J ournalism 6(2): 199- 219.

Clement E. Asante (1997). Press Freedom and Development, Bibliography, Greenwood Press, 1997, 216 pp

David Weaver, S. W. (2000, 2002). The Global Journalists, Watchdog Journalism in South America, Tradition and change in Nicharaguan Press.

David Weaver, S. W. (2000, 2002). The Global Journalists, Watchdog Journalism in South America, Tradition and change in Nicharaguan Press.

Fiss, O. M. (1986). Free Speech and Social Structure. Journal of Iowa Law Review, 71, 1405-1425.

FISS, O. M. (1990) Why the state? IN LICHTENBERG, J. (Ed.) Democracy and the Mass Media.

Hackett, R. A. (1985). A hierarchy of access: Aspects of source bias on Canadian TV news.

Hallin D C and Mancini P (2004) Comparing Media Systems: Three Models of Media and Politics. Cambridge University Media, Cambridge.

Hameed, A. (2016, January 16). Controller News. (A. Ashraf, Interviewer)

Hanitzsch, T. \& Mellado, C. (2011) 'What Shapes the News around the World? How Journalists in Eighteen Countries Perceive Influences on their Work', The International Journal of Press/Politics 16(3): 404-426.

Herman, E. S., \& Chomsky, N. (1988). Manufacturing consent: The political economy of the mass media. New York: Pantheon Books.

Joseph, M. K. (1997). Freedom of The Press. New Delhi: Anmol Publications. Journalism Quarterly, Journalism 
Quarterly, 50, 744-50.135

Khan, N. (2006). Pakistan in 2005. Lahore: Azeem.

Kim, S-S. (2002). Rethinking Newspaper Ownership, Control and Media Power. Journal of Korean Society for Journalism and Communication Studies, 46 (2), spring, 122-149.

Klaehn, J. (2005a) 'A critical review and assessment of Herman and Chomsky's

LaMay, C. L. (2007). Exporting press freedom: Economic and Editorial Dilemmas in International Media Assistance. New Brunswick (U.S.A.) and London (U.K.): Transaction Publishers.

Media Login Monthly Review, May (2015) retrieved October 10, 2016 from http://medialogic.com.pk/tam/wpcontent/uploads/2015/07/Medialogic_Monthly_Review_May-2015.pdf

Memon, B. (2014). Constraints in the Professionalization of Journalism in Pakistan: Ownership, Laws and Subjectivity. Global Media Journal , 1-9.

Rowan, D. (2015, November 05). How BuzzFeed mastered social sharing to become a media giant for a new era. Retrieved from Wired: http://www.wired.co.uk/magazine/archive/2014/02/features/buzzfeed

SA, E. S. (2009). Factors Influencing Freedom of the Press in South Korea: A Survey of Print Journalists' Opinions. Asian Social Science Vol 5 Number 3.

Saeed, S. (2009). Negotiating power: community media, democracy, and the public sphere, Development in Practice , 19(4), $466-478$.

Shoemaker, P. J., \& Reese, S. D. (1996). Mediating the message: Theories of influences on mass media content. White Plains, N.Y: Longman.

Shoemaker, Reese (2014), Mediating the Message in the 21st Century: A Media Sociology Perspective, Routledge

Siraj, S. A. (2008, October 21). Critical Analysis Of Press Freedom In Pakistan. Global Media Journal. Retrieved from Allama Iqbal Open University: http://www.aiou.edu.pk/gmj/artical1(b).asp

Stromback, Jesper, \& Karlsson, Michael. (2011). Who's Got the Power? Journalism Practice, 5 (6), 643 --656.

Thu, K. (2012). The Impact of Censorship on the Development of the Private Press Industry in Myanmar. England, UK: Reuters Institute Fellowship paper University of Oxford.

Waseem M (2006). The Electronic Media Explosion. Dawn Sunday, November 5. Derived December 26, 2007 from http://www.asiamedia.ucla.edu/article.

World Pres freedom Index 2015. (2015, October 20). Retrieved from Reporters Without Borders: http://index.rsf.org/\#!/ Yousuf, H. (2013). Mapping Digital Media, Pakistani . Open Society Foundation 